\begin{tabular}{|c|l|}
\hline Title & Isolation and identification of new vasodilative substances in diesel exhaust particles \\
\hline Author(s) & Seki, Koh-ichi; Noya, Yoichi; Mikami, Y usuke; Taneda, Shinji; Suzuki, A kira K.; Kuge, Y uji; Ohkura, Kazue \\
\hline Citation & $\begin{array}{l}\text { Environmental Science and Pollution Research, 17(3), 717-723 } \\
\text { https://doi.org/10.1007/311356-009-0207-4 }\end{array}$ \\
\hline Issue Date & 2010-03 \\
\hline Doc URL & http://hdl.handle.net/2115/44897 \\
\hline Rights & The original publication is available at www.springerlink.com \\
\hline Type & article (author version) \\
\hline File Information & ESPR17-3_717-723.pdf \\
\hline
\end{tabular}

Instructions for use 


\title{
Isolation and Identification of New Vasodilative Substances in Diesel Exhaust Particles
}

\author{
Yoichi Noya • Yusuke Mikami • Shinji Taneda • Akira K. Suzuki • Kazue Ohkura • Yuich Kuge • Koh-ichi Seki
}

\begin{abstract}
Goal, Scope, and Background We recently developed a new isolation method for diesel exhaust particles (DEP), involving successive extraction with $\mathrm{H}_{2} \mathrm{O}$, sodium bicarbonate, and sodium hydroxide, in which the sodium hydroxide extract was found to consist of phenolic components. Analysis of the extract revealed that vasodilative active nitrophenols are in DEP in significantly higher concentration than those estimated by an earlier method involving a combination of solvent extraction and repeated chromatography. These findings indicated that our new procedure offers a simple, efficient and reliable method for the isolation and identification of bioactive substances in DEP. This encouraged us to extend our work to investigating new vasodilatory substances in the sodium bicarbonate extract.

Materials and Methods DEP were collected from the exhaust of a 4JB1-type engine (ISUZU Automobile Co., Tokyo, Japan). GC-MS analysis was performed with a GCMS-QP2010 instrument (Shimadzu, Kyoto, Japan).

Results DEP dissolved in 1-butanol was successively extracted with water, sodium bicarbonate, and then aqueous sodium hydroxide. The sodium bicarbonate extract was neutralized and the resulting mixture of acidic components was subjected to reverse-phase (RP) column chromatography followed by RP-HPLC with fractions assayed for vasodilative activity. This led to the identification of telephthalic acid, $p$-hydroxybenzoic acid, isophthalic acid, phthalic acid, 3-hydroxy-4-nitrobenzoic acid, 4-hydroxy-3-nitrophenol, and 1,4,5-naphthalene tricarboxylic acid as components of DEP.

Discussion The sodium bicarbonate extract was rich in the acidic components. Repeated reverse-phase chromatography resulted in the successful isolation of several acidic substances including the new vasodilative materials, 4-hydroxy-3-nitrobenzoic acid and 3-hydroxy-4-nitrobenzoic acid.

Conclusion Our new fractionation method for DEP has made possible the isolation of new vasodilative compounds from the sodium bicarbonate extract.
\end{abstract}

Keywords Acidic components; Diesel exhaust particles; Fractionation; 3-Hydroxy-4-nitrobenzoic acid; 4-hydroxy-3-nitrobenzoic acid; Separation method; Vasodilatory compounds

\author{
Y. Noya • Yuichi Kuge • K. Seki $(\bowtie)$ \\ Central Institute of Isotope Science, \\ Graduate School of Medicine, \\ Hokkaido University, \\ Sapporo 060-0815, Japan \\ e-mail: seki@ric.hokudai.ac.jp \\ Y. Mikami • K. Ohkura \\ Department of Radiopharmaceutical Chemistry, \\ Faculty of Pharmaceutical Sciences, \\ Health Sciences University of Hokkaido, \\ Ishikari-Tobetsu 061-0293, Japan \\ S. Taneda • A. K. Suzuki \\ Environmental Nanotoxicology Section, \\ Research Center for Environmental Risk, \\ National Institute for Environmental Studies, \\ Tsukuba 305-8506, Japan
}




\section{Dilution tunnel}

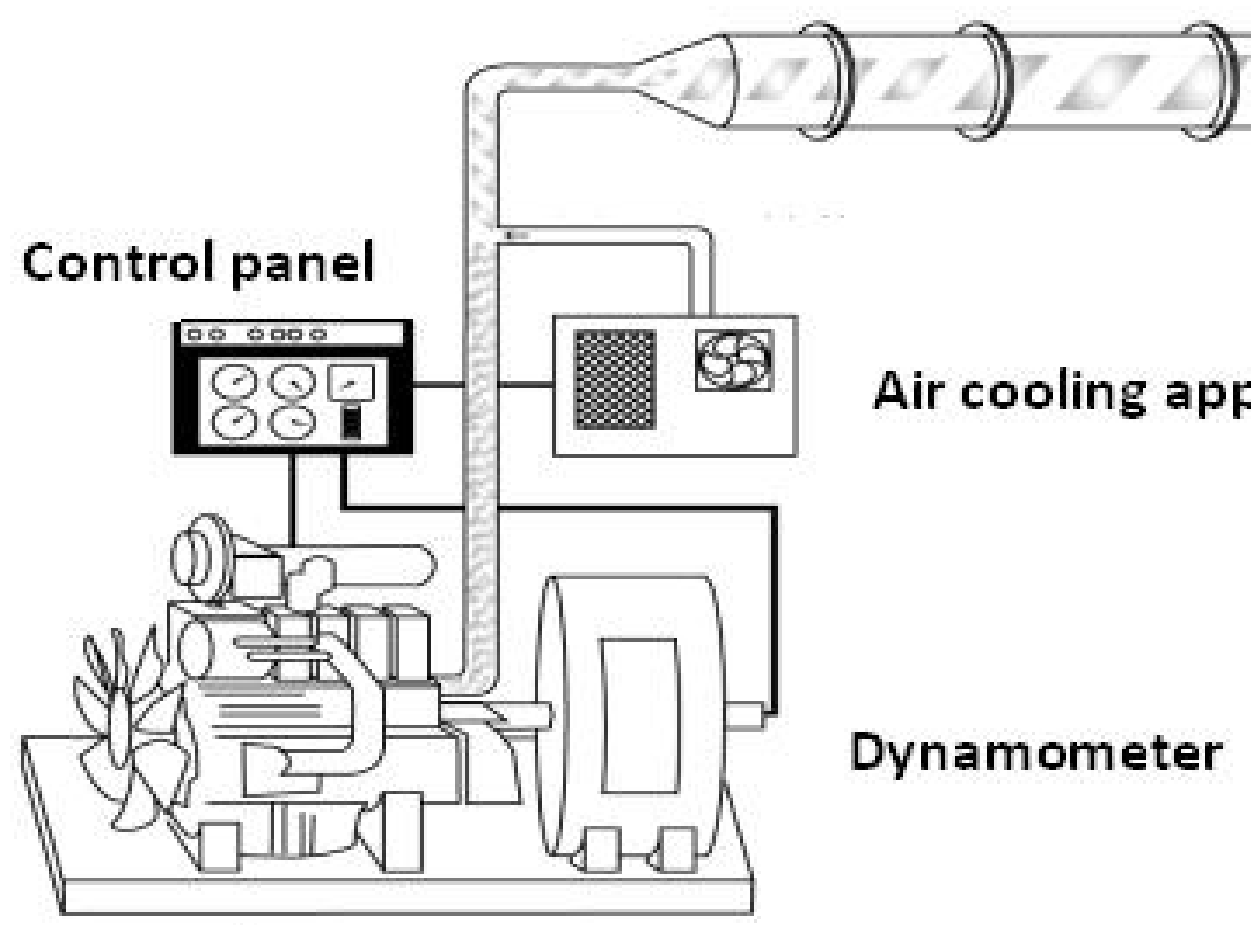

\section{Diesel engine}

Fig. 1

\subsection{Reagents}

Authentic samples of terephthalic acid (1), 4-hydroxybenzoic acid (2), isophthalic acid (3), dimethyl phthalate, dimethyl 4-methylphthalate, methyl 4-hydoxy-3-nitrobenzoate, methyl 3-hydoxy-4-nitrobenzoate, and trimethyl 1,4,5-naphthalenetricarboxylate for GC-MS analysis were purchased from Tokyo Kasei Kogyo Co. Ltd. (Tokyo, Japan). All other reagents were of analytical reagent grade.

\subsection{Instrumentation}

GC-MS analysis was performed at $70 \mathrm{eV}$ with a GCMS-QP2010 instrument (Shimadzu, Kyoto, Japan) equipped with a DB-5ms capillary GC column $(0.25 \mathrm{~mm} \times 30 \mathrm{~m}$; (Shimadzu, Kyoto, Japan). Analysis was carried out at a column temperature of $80-200^{\circ} \mathrm{C}$. NMR $-{ }^{1} \mathrm{H}$ - and ${ }^{13} \mathrm{C}-\mathrm{NMR}$ spectra were recorded at $400 \mathrm{MHz}$, in $\mathrm{CDCl}_{3}(\mathrm{EX} 400, \mathrm{JEOL}$, Tokyo, Japan). Chemical shifts are given in $\delta$ relative to tetramethylsilane (TMS, Tokyo Kasei Kogyo Co., Ltd. Tokyo, Japan) as the internal standard.

2.4 Measurement of Vascular Relaxation -Measurement of vasodilatory activity was made by using seven-month-old SPF F344 male rats (JCL:F344, CLEA Japan, Inc., Tokyo, Japan), which were maintained in a controlled room in terms of temperature $\left(22 \pm 1{ }^{\circ} \mathrm{C}\right)$, humidity $(50 \pm 5 \%)$ and ventilation $(25-30$ times/h). Lights were cycles at $12 \mathrm{~h}$ light-dark intervals. Food (CE-2 commercial diet, CLEA Japan, Inc.) and water were given ad libitum. The rats were anesthetized 
by pentobarbital sodium $(50 \mathrm{mg} / \mathrm{Kg}$, i.p.). After bleeding, the thoracic artery of each rat was excised and cut into $3 \mathrm{~mm}$ rings. The arterial ring was located in a magmus tube with $1 \mathrm{~g}$ of tonus and incubated in Locke-Ringer's solution ( $\mathrm{NaCl}$, $153.8 \mathrm{mM}$; KCl, $5.63 \mathrm{mM} ; \mathrm{CaCl}_{2}, 3.17 \mathrm{mM}$; glucose, $5.55 \mathrm{mM} ; \mathrm{NaHCO}_{3}, 2.38 \mathrm{mM}$; $\mathrm{pH} 7.4$ ) at $37{ }^{\circ} \mathrm{C}$ under aeration with $95 \% \mathrm{O}_{2}$ and $5 \% \mathrm{CO}_{2}$ for approximately $1 \mathrm{~h}$. After contraction of the thoracic artery rings with $10^{-6} \mathrm{M}$ phenylephrine (PE), substrates (4-methylphthalic acid, 4-hydroxy-3-nitrobenzoic acid and 3-hyroxy-4-nitrobenzoic acid), dissolved in PBS $\left(10^{-6}, 10^{-5}, 10^{-4}, 10^{-3}, 10^{-2}\right.$ and $\left.10^{-1} \mathrm{M}\right)$ containing $0.05 \%$ Tween 80 were accumulatively added into an organ bath. The changes in tension were amplified (FD pickup TB-612T transducer and Multichannel amplifier MEG-6108, Nihon Kohden, Tokyo, Japan) and recorded (Phoenix, DKK-TOA Co., Tokyo, Japan) (cf. Mori et al. 2003a).

\subsection{Extraction procedure from diesel exhaust particles (DEP)}

DEP (10 g) was dissolved in 1-butanol $(300 \mathrm{ml})$, and was first washed with water, then extracted with a saturated aqueous solution of sodium bicarbonate $\left(\mathrm{NaHCO}_{3} ; 100 \mathrm{ml} \times 5\right)$, and subsequently extracted with $10 \%$ aqueous $\mathrm{NaOH}$ $(100 \mathrm{ml} \times 3)$.

The combined $\mathrm{NaHCO}_{3}$ extracts were neutralized with $10 \% \mathrm{HCl}$, and then the solution was extracted with dichloromethane $(100 \mathrm{ml} \times 3)$. After drying over anhydrous sodium sulfate, the organic solution was evaporated to give an oily residue $(1.6 \mathrm{~g})$. The resulting oil was subjected to preparative HPLC (Inertsil ODS-3, GL Science) with water containing $0.1 \%$ formic acid, acetonitrile, and 1-butanol (70: $15: 15)$, to give 12 fractions (F1 - F12) (9.6 ml each). Samples from each fraction were tested for activity in the vascular relaxation assay. The fractions 3 (F3) (22.7 mg) and 4 (F4) (25.2 mg), that revealed significant vascular relaxation activity, were re-fractionated by HPLC (water containing $0.1 \%$ formic acid and acetonitrile $=70: 30)$ with monitoring of the UV-absorption at 254 nm. Thus, F3 was fractionated into eight subfractions; F3.1 (2.0 mg), F3.2 (2.2 mg), F3.3 (1.5 mg), F3.4 (1.1 mg), F3.5 (4.9 mg), F3.6 (1.4 mg), F3.7 (3.7 mg), F3.8 (3.1 mg). Similarly, F4 was separated into six subfractions; F4.1 (1.2 mg), F4.2 (1.4 mg), F4.3 (1.9 mg), F4.4 (0.6 mg), F4.5 (2.5 mg), F4.6 (7.3 mg) (Figure 2). Preliminary assays revealed that F3.5, F4.1, and F4.3 possessed vasodilative activity.

\section{Results}

Spectroscopic studies (LC-MS, GC-MS, ${ }^{1} \mathrm{H}-\mathrm{NMR}$ ) of each subfraction revealed that F3.1 was a mixture of telephthalic acid (1) and 4-hydroxybenzoic acid (2), F3.2, F3.3, and F3.5 were ascribed to isophthalic acid (3), phthalic acid (4), and 4-methylphthalic acid (5), respectively (Figure 3). Compounds 1, 2, and 3 were identified by comparison of their ${ }^{1} \mathrm{H}-\mathrm{NMR}$ spectra and chromatographic behaviors with those of the authentic samples: ${ }^{1} \mathrm{H}-\mathrm{NMR}$ of $\mathbf{1}\left(\mathrm{CD} \mathrm{DD}_{3} \mathrm{OD}\right) 8.09$ (4H, s, H-2, H-3, H-5 and H-6), ${ }^{1} \mathrm{H}-\mathrm{NMR}\left(\mathrm{CD}_{3} \mathrm{OD}\right)$ of $2 \delta: 6.79(2 \mathrm{H}, \mathrm{dt}, J=8.6,2.3 \mathrm{~Hz}, \mathrm{H}-3 \mathrm{and} \mathrm{H}-5), 7.86(2 \mathrm{H}, \mathrm{dt}, J=$ 8.6, $2.3 \mathrm{~Hz}, \mathrm{H}-2$ and H-6)), F3.2, F3.3, and ${ }^{1} \mathrm{H}-\mathrm{NMR}\left(\mathrm{CD}_{3} \mathrm{OD}\right)$ of $3 \delta .7 .58(1 \mathrm{H}, \mathrm{t}, J=7.5 \mathrm{~Hz}, \mathrm{H}-5), 8.21(2 \mathrm{H}, \mathrm{dd}, J=$ $1.8,7.5 \mathrm{~Hz}, \mathrm{H}-4$ and H-6), $8.64(1 \mathrm{H}, \mathrm{t}, J=1.8 \mathrm{~Hz}, \mathrm{H}-2)$. The structures of phthalic acid $\left(4,{ }^{1} \mathrm{H}-\mathrm{NMR}\left(\mathrm{CD}{ }_{3} \mathrm{OD}\right) \delta: 7.56\right.$ $(2 \mathrm{H}, \mathrm{dd}, J=5.7,3.5 \mathrm{~Hz}, \mathrm{H}-3$ and H-4), $7.72(2 \mathrm{H}, \mathrm{dt}, J=5.7,3.5 \mathrm{~Hz}, \mathrm{H}-2$ and H-5)) and 4-methylphthalic acid (5, ${ }^{1} \mathrm{H}-\mathrm{NMR}\left(\mathrm{CD}_{3} \mathrm{OD}\right) \delta: 2.41\left(3 \mathrm{H}, \mathrm{s}, \mathrm{C}^{4}-\mathrm{CH}_{3}\right), 7.37(1 \mathrm{H}, \mathrm{d}, J=8.0 \mathrm{~Hz}, \mathrm{H}-5), 7.49(1 \mathrm{H}, \mathrm{s}, \mathrm{H}-3), 7.66(1 \mathrm{H}, \mathrm{d}, J=8.0 \mathrm{~Hz}$, H-6)) were confirmed by comparison of the GC-MS data of their methyl ester derivatives (6 and 7) with those of the authentic samples: MS for 6 (m/z); $194\left(\mathrm{M}^{+}, 10 \%\right), 183$ (base peak), 7 (m/z); M $^{+}, 208$ (15\%), 177 (base peak). Similarly, F4.1, F4.3, and F4.6 were identified as 4-hyroxy-3-nitrobenzoic acid (8) $\left({ }^{1} \mathrm{H}-\mathrm{NMR}\left(\mathrm{CD}_{3} \mathrm{OD}\right) \delta\right.$ : $7.19(1 \mathrm{H}, \mathrm{d}, J$ $=8.6 \mathrm{~Hz}, \mathrm{H}-5), 8.17(1 \mathrm{H}, \mathrm{dd}, J=1.7,8.6 \mathrm{~Hz}, \mathrm{H}-6), 8.65(1 \mathrm{H}, \mathrm{d}, J=1.7 \mathrm{~Hz}, \mathrm{H}-2))$, 3-hyroxy-4-nitrobenzoic acid (9) $\left({ }^{1} \mathrm{H}-\mathrm{NMR}\left(\mathrm{CD}_{3} \mathrm{OD}\right) \delta: 7.57(1 \mathrm{H}, \mathrm{dd}, J=1.7,8.6 \mathrm{~Hz}, \mathrm{H}-6), 7.71(1 \mathrm{H}, \mathrm{d}, J=1.7 \mathrm{~Hz}, \mathrm{H}-2), 8.07(1 \mathrm{H}, \mathrm{d}, J=8.6 \mathrm{~Hz}, \mathrm{H}-5)\right)$, and 1,4,5-naphthalenetricarboxylic acid (10), respectively (Figure 4) by comparison of the GC-MS spectra of their methyl esters $(\mathbf{1 1}, \mathbf{1 2}, \mathbf{1 3})$ with those of authentic samples (Figure 5, 6, 7). The result of the fractionation was summarized in Table 1. 4-Hydroxy-3-nitrobenzoic acid (8), and 3-hyroxy-4-nitrobenzoic acid (9) clearly demonstrated vasodilative activity. 4-Methylphthalic acid (5) showed vasodilative activity, though the effect was only transient and weaker than 8 and 9. The lowest concentrations of 4-methylphthalic acid (5), 4-hydroxy-3-nitrobenzoic acid (8), and 3-hyroxy-4-nitrobenzoic acid (9) causing vasodilatory activity were estimated as $\sim 10^{-3} \mathrm{M}$ (Figure 8 ). 


\section{Discussion}

Although a number of studies have demonstrated epidemiologically important results, none of the investigations focused on a systematic separation and characterization of the bioactive components of DEP until our initial work on the isolation and identification of such entities by using a method involving successive solvent extractions, and subsequent repeated column chromatography. In spite of poor fractionation and a significant lack of accuracy and reproducibility associated with this method, such isolated compounds as phenanthlenes (Mori et al. 2003b), dibenzothyophenes (Mori et al. 2003c), alkylphenols (Taneda et al. 2004c), hydroxyphthalic acids (Mori et al 2003d), and vasodilative active nitrophenols (Mori et al. 2003a) suggest that the constituents of DEP can be broadly classified into the following groups: (i) aromatic carboxylic acids, (ii) phenol derivatives, (iii) non-combustible neutral compounds. They are thus amenable to separation by using a conventional acid-base extraction procedure.

Based on this concept, we have developed the new fractionation scheme used for this work (Noya et al. 2008). The sodium bicarbonate extract obtained by this procedure has been shown to contain various aromatic carboxylic acids including the new vasodilatory nitro-compounds, 4-hydroxy-3-nitrobenzoic acid (8) and 3-hyroxy-4-nitrobenzoic acid (9). 4-Methylphthalic acid (5) revealed vasodilative activity, but the effect was only temporary and feeble, suggesting that different pharmacological mechanism might be involved in $\mathbf{5}$ from that of nitrophenols.

Although vascular relaxation effects of the newly isolated 4-hydroxy-3-nitrobenzoic acid (8) and 3-hyroxy-4-nitrobenzoic acid (9) are much weaker $\left(\sim 10^{-3} \mathrm{M}\right)$ than those reported for nitrophenols (active at threshold concentrations of $\sim 10^{-4} \mathrm{M}$ ), the contents of the newly isolated vasodilatory components are as high as those of nitrophenols (Table 1). These findings may be important from the environmental perspective, as remarkable amounts of DEP are exhausted into the air; for example, $58902 \mathrm{t}$ in Japan (Japan Environmental Agency 1998), $111530 \mathrm{t}$ in the United States (United States Environmental Protection Agency 1999), 37000 t in England (Airborne Particles Expert Group 1999), and $240000 \mathrm{t}$ in Europe (Petroleum Energy Center Japan 1999). Many automobile companies either in Japan or European countries are competitively developing modern Diesel cars equipped with different types of exhaust treatment such as a particulate trap/filter to detoxify diesel exhaust. Swiss researchers very recently investigated the secondary effects of catalytic diesel particulate filters on the coversion of polyaromatic hydrocarbons (PAHs) versus formation of nitro-polyaromatic hydrocarbons (nito-PAHs), whereby PAHs were reduced by using filters, while they noticed the formation of selected nitro-PAHs (Norbert V. Heeb et al. 2008). Although our present investigation was performed on the DEP collected from an engine without using a filter, we have demonstrated significant amounts of vasodilative nitro compounds are consisted in DEP, and their hazardous effects on human health cannot be ignored because of the vast amount of DEP emitted into the environment.

\section{Conclusions}

Our present work reports new vasodilative active nitro substances in DEP, which are released in significant amounts from Diesel engines into the air. Because of the simple and systematic isolation procedure, the present analytical method, involving a combination of acid-base extraction and subsequent chromatography with monitoring of bioactivity, would serve as a facile and efficient method for identification of such bio-hazardous substances as vasodilator, carcinogen, and in DEP.

Acknowledgement This study was supported in part by a grant from the Japan Society for the Promotion of Science (Basic Research C-17510052). KK gratefully acknowledges Dr. Nagara Tamaki (Hokkaido University) and Dr. Raymond Jeremy Hugh Davies (Emeritus professor, Queens University Belfast) for their constructive comments and suggestions.

\section{References}

Airborne Particles Expert Group (1999) Source apportionment of airborne particulate matter in the Unnited Kingdom. United Kingdom Department of Environment, Transport and Regions, The Welsh Office, the Scottish Office and the Department of Environment (north Ireland) 9-37.

Bayona JM., Markides KE, Lee M (1988) Characterization of polar polycyclic aromatic compounds in a heavy-duty diesel exhaust particulate by capillary column gas chromatography and high-resolution mass spectrometry. Environ Sci 
Technol 22:1440-1447

Draper WM (1986) Quantitation of nitro- and dinitropolycyclic aromatic hydrocarbons in diesel exhaust particulate matter. Chemosphere 15:437-447

Erdinger L, Durr M, Hopker KA (2005) Correlations between mutagenic activity of organic extracts of airborne particulate matter, $\mathrm{NO}_{\mathrm{x}}$, and sulphur dioxide in southern Germany - Results of a two-year study. Env Sci Pollut Res 12:10-20

Furuta C, Li CM, Taneda S, Suzuki AK, Kamata K, Watanabe G, Taya K (2005) Immunohistological study for estrogenic activities of nitrophenols in diesel exhaust particles. Endocrine 27:33-36

Furuta C, Suzuki AK, Taneda S, Kamata K, Hayashi H, Mori Y, Li C, Watanabe G, Taya K (2004) Estrogenic activities of nitrophenols in diesel exhaust particles. Biol Report 70:1527-1533

Hayatsu M, Hirano M, Tokuda S (2000) Involvement of two plasmids in fenitrothion degradation by Burkholderia sp. strain NF100. Appl Environ Microbiol 66:1737-1740

Ichinose T, Yajima Y, Nagashima M, Takenoshita S, Nagamachi Y, Sagai M (1997) Lung carcinogenesis and formation of 8-hydroxy-deoxyguanosine in mice by diesel exhaust particles. Carcinogenesis 18:185-192

Japan Environmental Agency (1998) The research on the total amount of emission and automobile exhaust source unit-the NOX according to object automobile in the usual transit 200-203

Kim TS., Kim JK, Choi K, Stenstrom MK, Zoh KD (2006) Degradation mechanism and the toxicity assessment in $\mathrm{TiO}_{2}$ photocatalysis and photolysis of parathion. Chemosphere 62:926-933

Li CM, Takahashi S, Taneda S, Furuta C, Watanabe G, Suzuki AK, Taya K (2006a) Impairment of testicular function in adult male Japanese quail (Coturnix japonica) after a single administration of 3-methyl-4-nitrophenol in diesel exhaust particles. J Endocrinol 189:555-564

Li CM, Taneda S, Suzuki AK, Furuta C, Watanabe G, Taya K (2006b) Anti-androgenic activity of 3-methyl-4-nitrophenol in diesel exhaust particles. Eur J Pharmacol 543:194-199

Li CM, Taneda S, Suzuki AK, Furuta C, Watanabe G, Taya K (2006c) Estrogenic and anti-androgenic activities of 4-nitrophenol in diesel exhaust particles. Toxicol Appl Pharmacol 217:1-6

Li CM, Taneda S, Suzuki AK, Furuta C, Watanabe G, Taya K (2006d) Effects of 3-methyl-4-nitrophenol in diesel exhaust particles on the regulation of testicular function in immature male rats. J Androl 28:252-258

McClellan RO (1987) Health effects of exposure to diesel exhaust particles. Annu Rev Pharmacol Toxicol 27:279-300

Mestres R (2005) Green chemistry - Views and strategies. Env Sci Pollut Res 12:128-132

Miyabara Y, Ichinose T, Takano H, Lim HB, Sagai M (1998) Effects of diesel exhaust on allergic airway inflammation in mice. J Allergy Clin Immunol 102:805-812

Mori Y, Kamata K, Toda N, Hayashi H, Seki K, Taneda S, Yoshino S, Sakushima A, Sakata M, Suzuki AK (2003a) Isolation of nitrophenols from diesel exhaust particles (DEP) as vasodilatation compounds. Biol Pharm Bull 26:394-395

Mori Y, Taneda S, Kamata K, Sakushima A, Hayashi H,. Suzuki AK, Sakata M, Yoshino S, Sagai M, Seki K (2003b) Identification of Phenanthrene and Related Compounds in Diesel Exhaust Particles by Gas Chromatography-mass Spectrometry. Environmental Sciences 10:187-192.

Mori Y, Taneda S, Kamata K, Sakushima A, Hayashi H,. Suzuki AK, Sakata M, Yoshino S, Sagai M, Seki K (2003c) Identification of Alkyldibenzothiophenes in Diesel Exhaust Particles by Gas Chromatography-mass Spectrometry. Environmental Sciences 10:157-164.

Mori Y, Taneda S, Sakushima A, Hayashi H, Kamata K, Suzuki AK, Sakata M, Yoshino S, Sagai M, Seki K (2003d) Isolation and Characterization of Hydroxyphthalate Derivatives in Diesel Exhaust Particles. Environmental Sciences 10: 51-54

Morville S, Scheyer A, Mirabel P, Millet M (2006) Spatial and geographical variations of urban, suburban and rural atmospheric concentrations of phenols and nitrophenols. Env Sci Pollut Res 13:83-89

Muranaka M, Suzuki S, Koizumi K, Takafuji S, Miyamoto T, Ikemori R, Tokiwa H (1986) Adjuvant activity of diesel-exhaust particulates for the production of IgE antibody in mice. J Allergy Clin Immunol 77:616-623

Norbert V. Heeb, Peter Schmid, Martin Kohler, Erika Gujer, Markus Zennegg, Daniela Wenger, Adrian Wichser, Andrea Ulrich, Urs Gfeller, Peter Honegger, Kerstin Zeyer, Lukas Emmenegger, Jean-Luc Petermann, Jan Czerwinski, Thomas Mosimann, Markus Kasper, and Andreas Mayer (2008) Secondary effects of catalytic diesel particulate filters: conversion of PAHs versus Formation of nitro-PAHs. Environ. Sci. Technol 42:3773-3779

Noya, Y Mikami, Y Taneda, S Mori, Y Suzuki, A. K Ohkura, K Yamaki, K Yoshino, S, Seki K-I (2008) Improvement of a Facile and Efficient Separation Method for Chemicals in Diesel Exhaust Particles: Analysis of the Contents of Nitrophenols. Env Sci Pollut Res 15:318-321.

Ona LF, Melinda A, Alberto P, Prudente JA, Sigua GC (2006) Levels of lead in urban soils from selected cities in a central region of the Philippines. Env Sci Pollut Res 13:177-183

Petroleum Energy Center Japan (1999) Workshop report with the European experts 9-37.

Sagai M, Furuyama A, Ichinose T (1996) Biological effects of diesel exhaust particles (DEP). III. Pathogenesis of asthma like symptoms in mice. Free Radical Biol Med 21:199-209

Sagai M, Saito H, Ichinose T, Kodama M, Mori Y (1993) Biological effects of diesel exhaust particles. I . In vitro production of superoxide and in vivo toxicity in mouse. Free Radical Biol Med 14:37-47

Schuetzle D (1983) Sampling of vehicle emissions for chemical analysis and biological testing. Environ Health Perspect 47:65-80

Schuetzle D, Lewtas J (1986) Bioassay-directed chemical analysis in environmental research. Anal Chem 58:1060A-1075A

Seidel B, Alm M, Peters R, Kordell W, Schaffer A (2006) Safety evaluation for a biodiesel process using prion-contaminated animal fat as a source. Env Sci Pollut Res 13:125-130

Takafuji S, Suzuki S, Koizumi K, Tadokoro K, Miyamoto T, Ikemori R, Muranaka M (1987) Diesel-exhaust particulates inoculated by the intranasal route have an adjuvant activity for IgE production in mice. J Allergy Clin Immunol 79:639-645

Taneda S, Kamata K, Hayashi H, Toda N, Seki K, Sakushima A, Yoshino S, Yamaki K, Sakata M, Mori Y, Suzuki AK 
(2004a) Investigation of vasodilatory substances in diesel exhaust particles (DEP) Isolation and identification of nitrophenol derivatives. J Health Sci 50:133-141

Taneda S, Mori Y, Kamata K, Hayashi H, Furuta C, Li C, Seki K, Sakushima A, Yoshino S, Yamaki K, Watanabe G, Taya K, Suzuki AK (2004b) Estrogenic and anti-androgenic activity of nitrophenols in diesel exhaust particles (DEP). Biol Pharm Bull 27:835-837

Taneda S, Mori Y, Sakushima Akiy, Kamata K, Hayashi H, Seki K, Sakata M, Yoshino S, Yamaki K, Sagai M, and Suzuki AK, (2004c) Separation and characterization of alkyltrimethylbenzene derivatives in diesel exhaust particles (DEP). Environmental Sciences, 11, 171-178.

Tsukue N, Toda N, Sagai M, Watanabe G, Taya K, Tsubone H, Suzuki AK (2002) Diesel exhaust particulate extract (DEPE)-induced abnormal parturition associated with increased myometrial contractility in C57BL mice. Environ Sci 9:355-367

Tsukue N, Toda N, Tsubone H, Sagai M, Jin WZ, Watanabe G, Taya K, Birumachi J, Suzuki AK (2001) Diesel exhaust (DE) affects the regulation of testicular function in male Fischer 344 rats. J Toxicol Environ Health A 63:115-126

United States Environmental Protection Agency (1999) Analysis of the impacts of control program on motor vehicle toxics emissions and exposure in urban areas and nationwide EPA420-R-99-029:120.

Watanabe N, Oonuki Y (1999) Inhalation of diesel engine exhaust affects spermatogenesis in growing male rats. Environ Health Perspect 107:539-544

Yoshida S, Sagai M, Oshio S, Umeda T, Ihara T, Sugamata M, Sugawara I, Takeda K (1999) Exposure to diesel exhaust affects the male reproductive system of mice. Int J Androl 22:307-315 
Table 1. Representative components isolated from the sodium bicarbonate extract of DEP $(\mathrm{mg} / \mathrm{kg})$

\begin{tabular}{lcccccc}
$\begin{array}{l}\text { Compound } \\
\text { (Fraction) }\end{array}$ & $3^{\mathrm{a}}$ & $4^{\mathrm{b}}$ & $5^{\mathrm{c}}$ & $8^{\mathrm{d}}$ & $9^{\mathrm{e}}$ & $\mathbf{1 0}^{\mathrm{f}}$ \\
$(\mathrm{F} 3.2)$ & $(\mathrm{F} 3.3)$ & $(\mathrm{F} 3.5)$ & $(\mathrm{F} 4.1)$ & $(\mathrm{F} 4.3)$ & $(\mathrm{F} 4.6)$ \\
\hline Content & 220 & 150 & 490 & 120 & 190 & $730 \mathrm{mg}$ \\
\hline
\end{tabular}

a) isophthalic acid, b) phthalic acid, c) 4-methylphthalic acid, d) 4-hyroxy-3-nitrobenzoic acid, e) 3-hyroxy-4-nitrobenzoic acid, f) 1,4,5-naphthalenetricarboxylic acid. 
Fig. 1 DEP collection procedure.

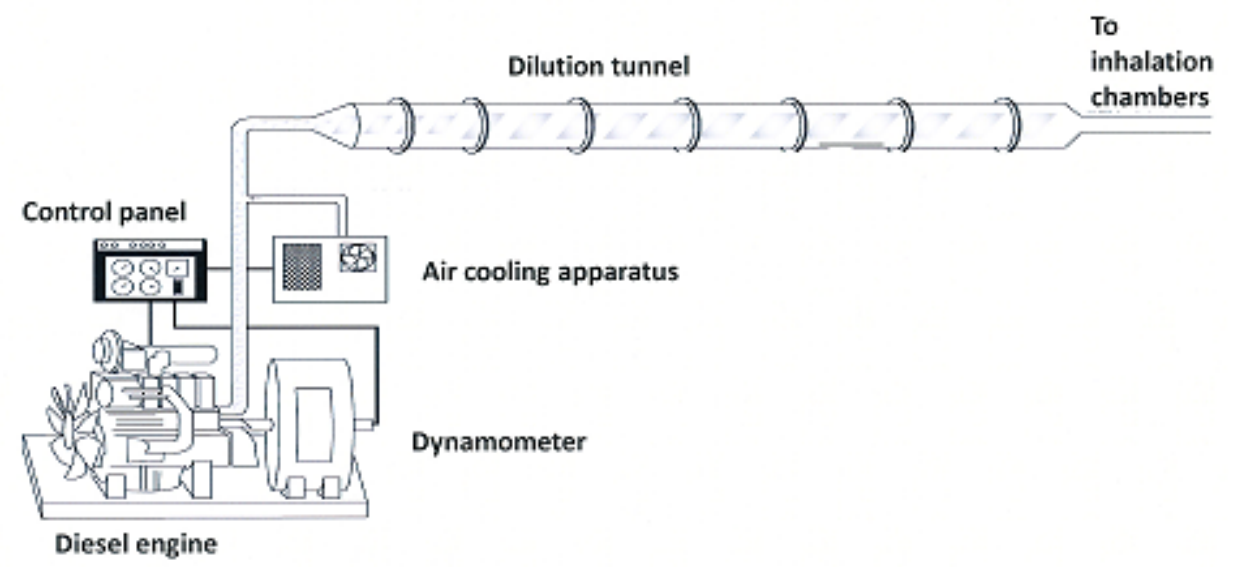


Fig. 2 Fractionation of $\mathrm{NaHCO}_{3}$ extract by HPLC

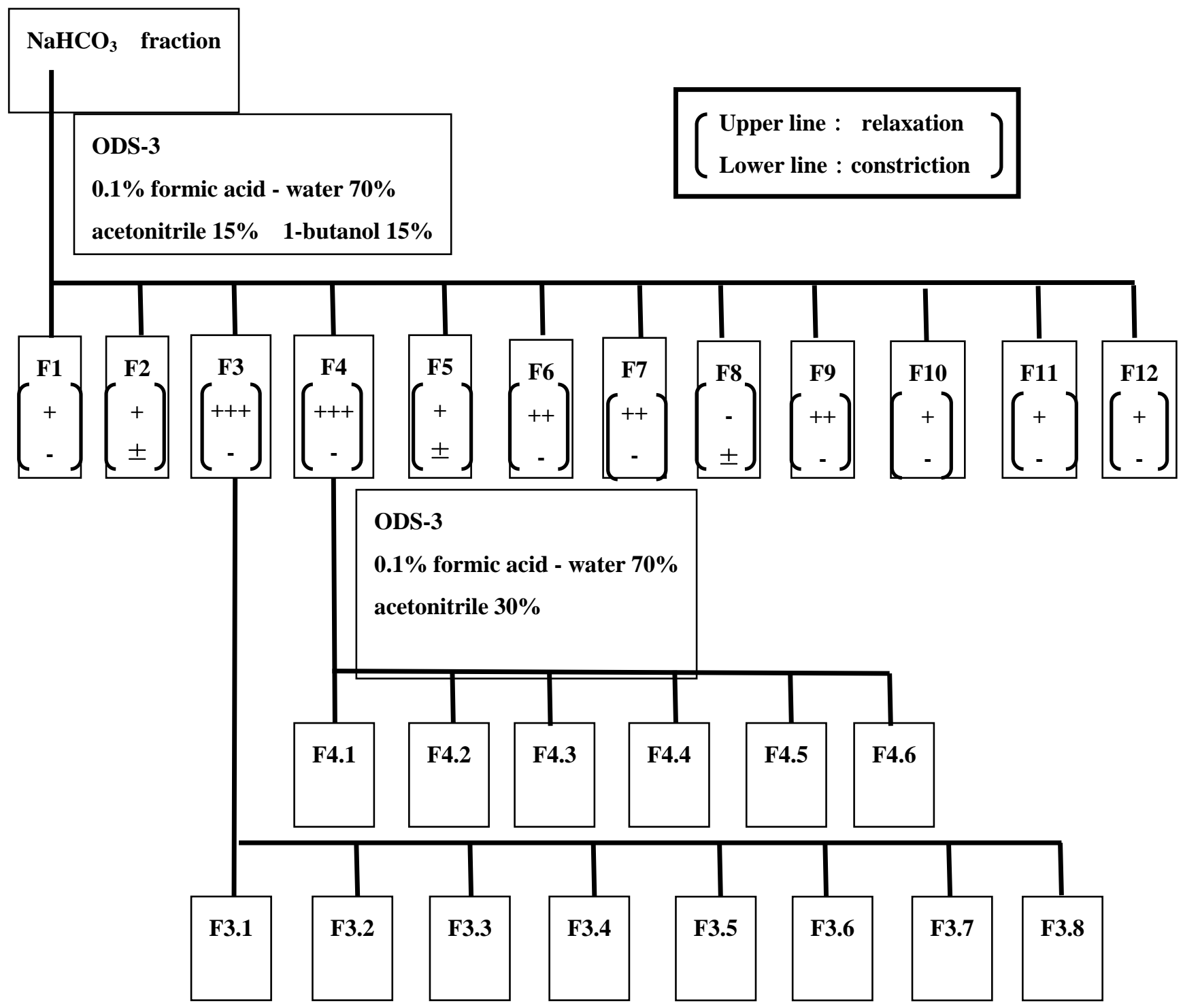


Fig. 3 Compounds isolated from fraction 3

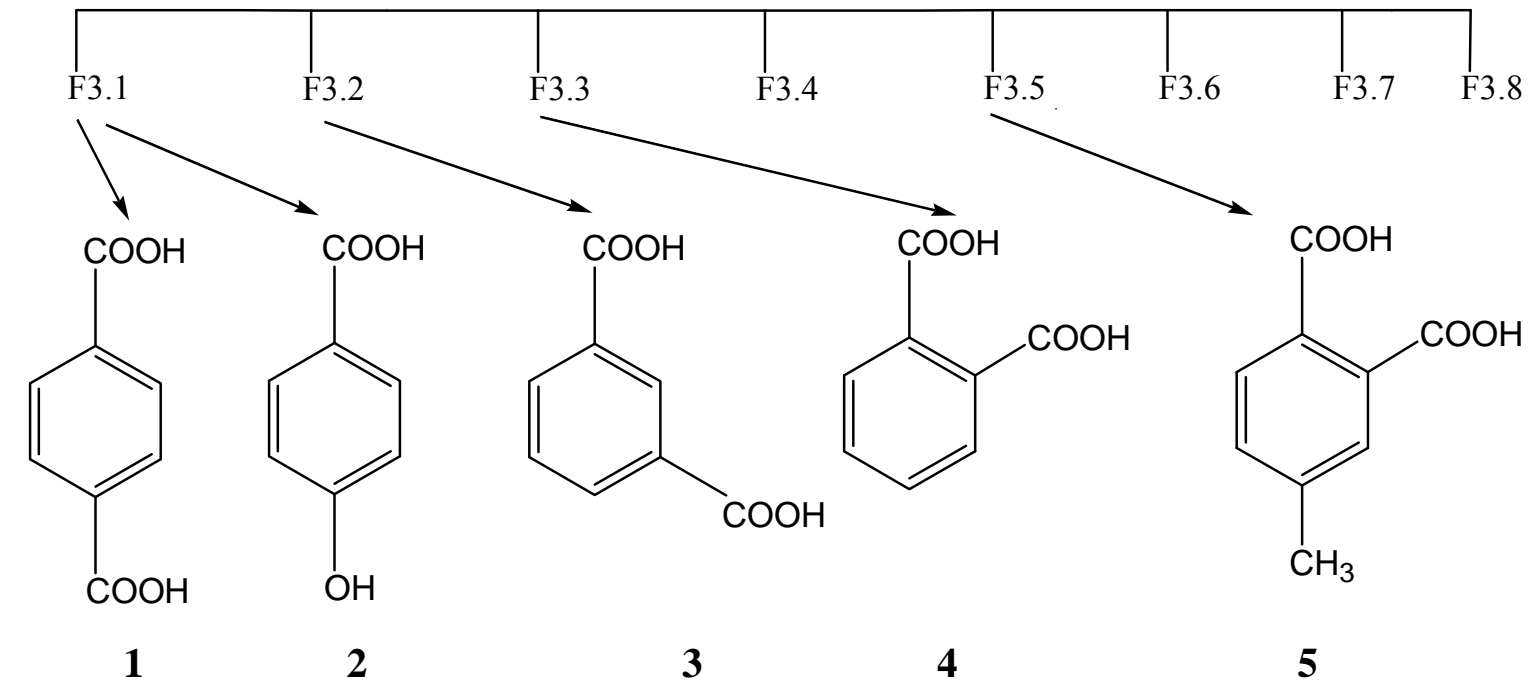


Fig. 4 Compounds isolated from fraction 4

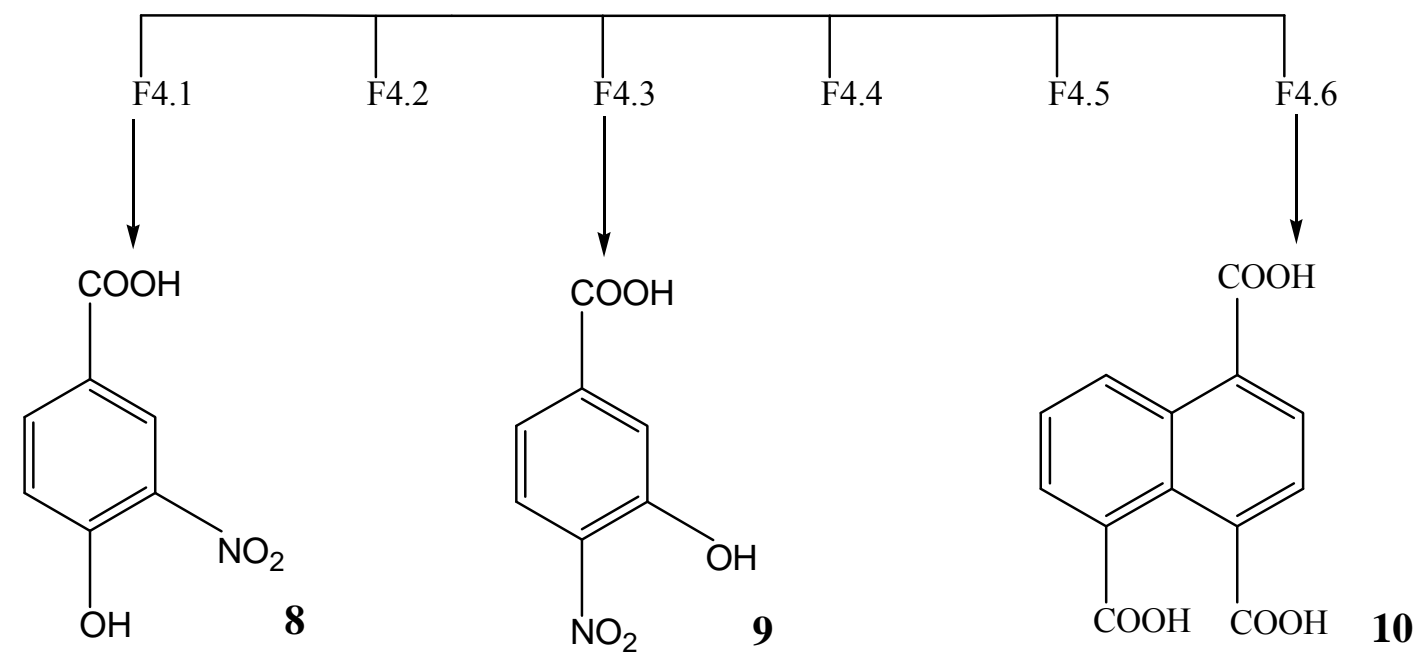


Fig. 5 MS spectrum of 8 (11)

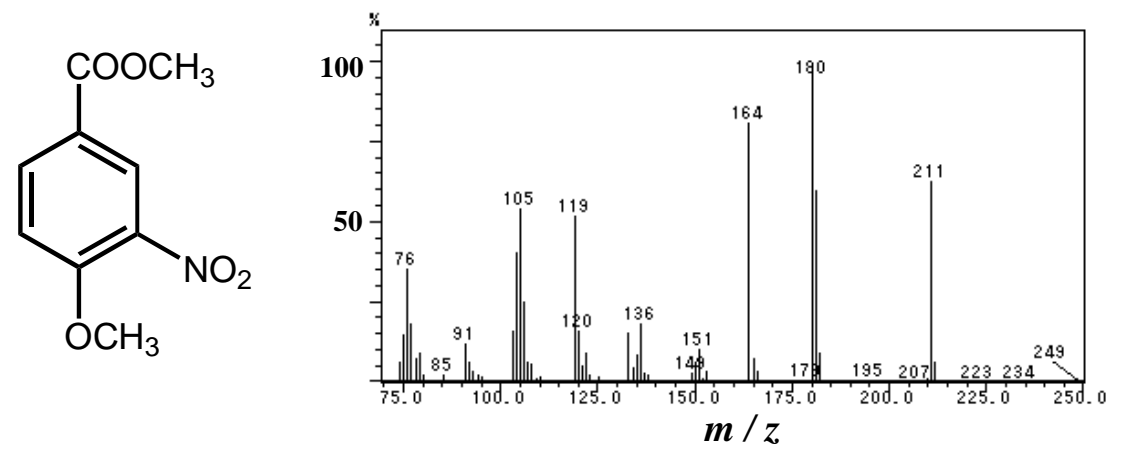


Fig. 6 MS spectrum for methyl ester of 9 (12)

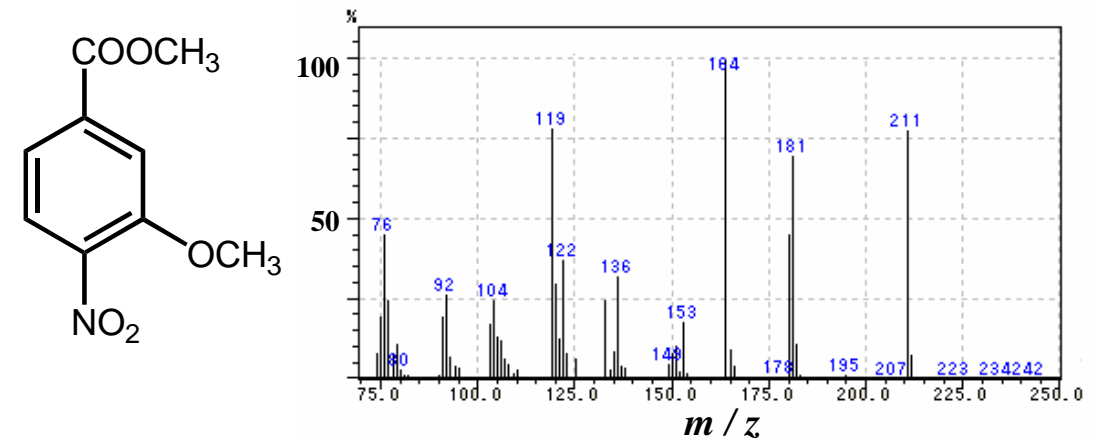


Fig. 7 MS spectrum of 10 (13)<smiles>COC(=O)c1ccc(C(=O)OC)c2c(C(C)=O)cccc12</smiles>

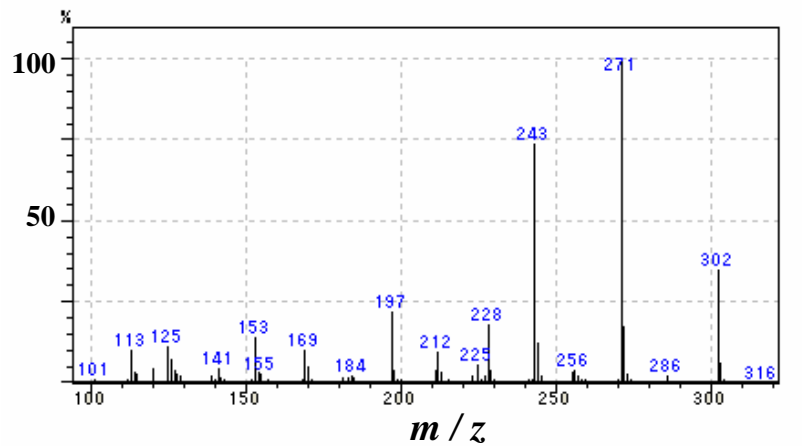


Fig. 8 Measurement of Vasodilatory activity for $\mathbf{8}, \mathbf{9}$, and $\mathbf{5}$

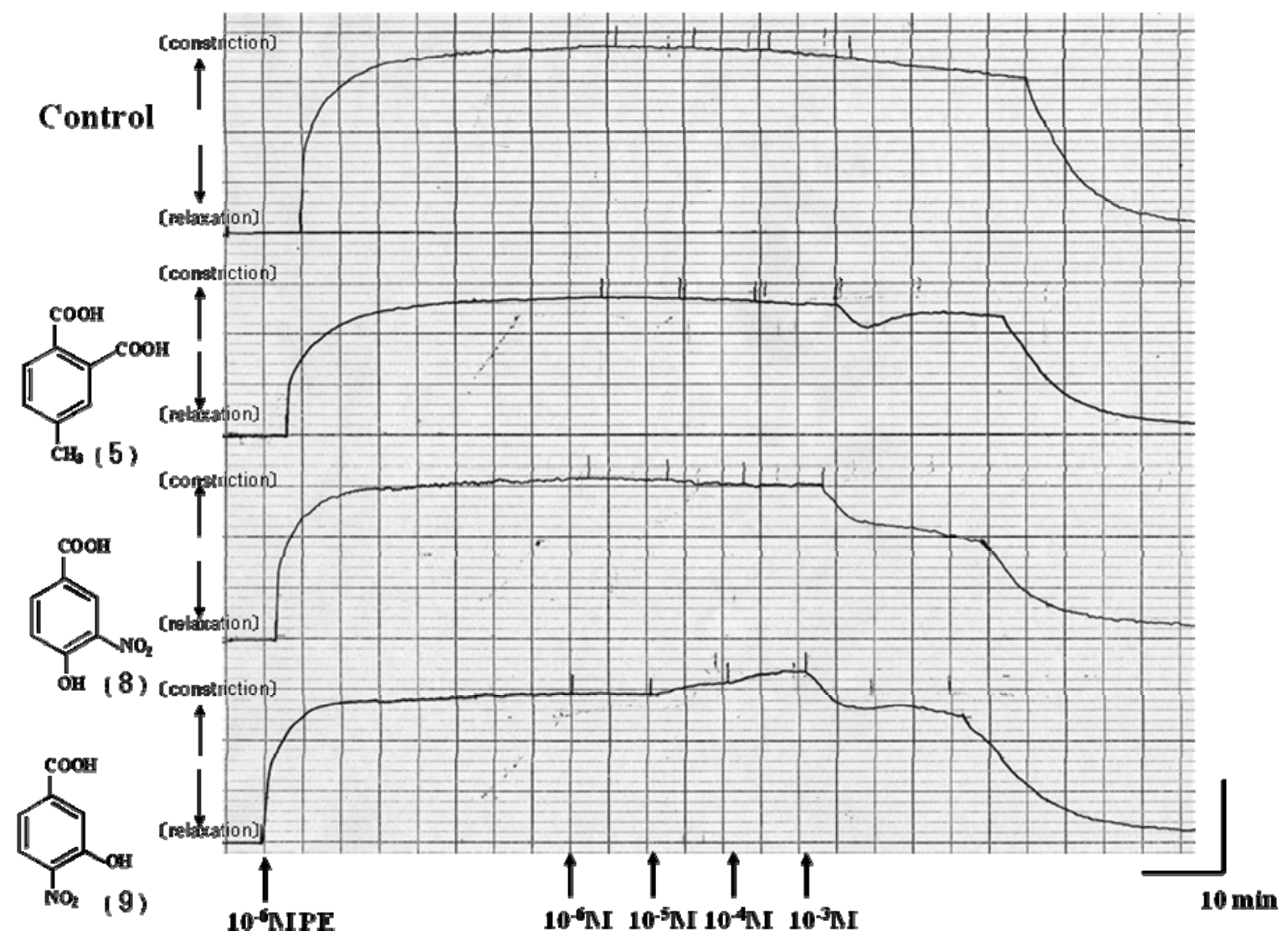

